\title{
A Development Design of Digital Story Conceptual Change-Oriented in Physics Subject
}

\author{
Yudi Kurniawan ${ }^{1}$, Riski Muliyani ${ }^{2}$. \\ STKIP Singkawang, Indonesia ${ }^{1,2}$ \\ yudikurniawan1012@gmail.com ${ }^{1}$, kikiriski1012@gmail.com²
}

Received: August $6^{\text {th }}, 2019$. Revised: September $11^{\text {th }}, 2019$. Accepted: September $12^{\text {th }}, 2019$

\section{Keywords:}

Digital Story; Conceptual

Change Oriented; ADDIE

Design; Learning Aspects

\begin{abstract}
The result of need analysis shown that are difficulties still exist for teachers and students if they are learning in the new condition immediately. Therefore, this study aims to provide learning tools in the digital form and called as digital story conceptual change oriented (DSCC). This research was research and development by using ADDIE (analysis, design, development, implementation, and evaluation) design. This media tested in a small scale test. The product designed on the subject of physics (Heat and Temperature) was validated by experts and tested on 147 respondents from Junior High School in West Singkawang and Central Singkawang sub-disctrict. The developed design was measured based on Learning Aspect (LA) which consists of: 1) Contextual problems, 2) Solution / Answer to the problem, 3) Communication effectiveness. The results of small-scale product trials shown that the Problem Solution aspect got the highest percentage of 93\% and the communication aspect becomes the lowest with $73 \%$ while also having the worst responses with a percentage of $10 \%$. This study could be references for researchers to improve the product to be better media and it could be so that it can be used directly and produce good learning outcomes.
\end{abstract}

\section{INTRODUCTION}

Misconceptions are problems in learning process that it exists all the time. This misconception has spread in various places. Therefore, misconceptions can be considered to be a common problem in education [1]. In the process, the existence of misconceptions becomes an obstacle that must be resolved by the teacher because misconceptions can spread, are resistant, cross gender, and across cultures [2]. On the other hand, rapid technological change in the 21 st century also creates problems for teachers. The teachers must be able and skilled in the use of multimedia or media development by using technology devices or computer software into their class [3]. Moreover, with technology, the availability of multimedia audio and video for learning can increase students' interest in learning [4]. 
To anticipate these changes, teachers usually take practical steps by using innovative learning models including POE, Interactive lecture demonstrations (ILD), the PDEODE model, and Inquiry model. Sometimes, teachers also used teaching methods that were rarely done in class such as demonstration methods and experimental methods. Some teachers used learning tool in their class such as in the form of reading texts (print-out), namely refutation text, conceptual change text, and text based analogy. But unfortunately, the change in learning models drastically still leaves problems in the psychological aspect and skills aspects. Psychologically, students feel they are not accustomed to using new learning activities (for example experiment) so that students being awkward and rigid. And this method affected their skill because they were bounded by standardized procedures and even strict controlling of variables [4]. The consequences of these method were students' performance is not maximal [5]. A practical solution is needed to prevent the occurrences of new problems when the teacher makes changes in their teaching process in the classroom. In this study, the solution offered was implementing of digital stories in learning. There have been many studies on digital stories, especially on various aspects, for example in elementary school children [6], in junior high school children [7], in the parents/ adult community [8], in the study of language and arts [9], mathematics studies [10], and physics study [11]. Although research on digital stories has been done a lot, there is still a little bit of study which explores digital story creation for the need for conceptual change studies $[6,12]$.

In this study, we develop the digital story conceptual change-oriented (DSCC). This solution gives an opportunity for teacher creates a pleasant learning environment. Another study stated that implementing the digital story could attract and engages students through fine contents because its usage was very easy [7]. In this study, digital story with technology integration is used as a teaching medium to involve students in the process of thinking, contextual phenomenon analysis and involvement in the scientific process (observation) of the phenomena [6]. Digital story is able to provide equal opportunities to students with diverse abilities to learn effectively and efficiently using smartphones, tablets even outside the formal classroom [13]. So, we concluded that the digital story can be used as reflective, active, enjoyable learning and can even be applied both by teachers and students. Teachers can use digital stories to deliver lesson content, presentations reinforcing concepts and reviewing material. And the other benefits area students allowed to create stories to share experiences, reflex their understanding and determine the theme they like or not. Based on the background, the purpose of this study is to develop the learning media which can reduce the number of student that held misconceptions as called as digital stories conceptual change oriented (DSCC). The result of this study could be valuable feedback for completing this developmental of this learning media.

\section{METHOD}

This research is development research with ADDIE Design a limited design on product pilot study on a small scale. All students in Center Singkawang and West Singkawang became the population. The sample of this study selected by cluster random were 147 students. For this design it is drawn on the flow chart in Fig.1.

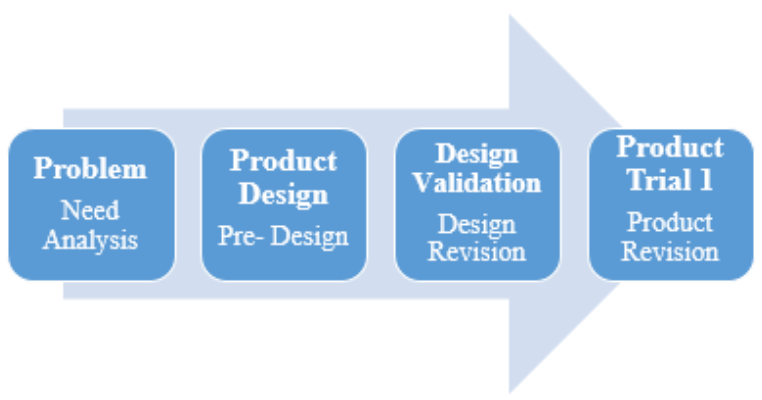

Fig 1. Design of DSCC research 
The collecting data technique used in this study by using rubric sheet. This instrument gave to the students (as user of DSCC) and to the teachers (as operator) in the class. Before it implemented in the class, the product has validated by experts. In the stage of determining the problem, researchers first determine whether this product is feasible enough to be developed. Therefore, in the field it was found that many teachers were unfamiliar with practicum tools so that it was difficult to conduct simple experiments in the laboratory, teachers were also worried that the time designed to do so many practical exercises would disrupt the target subject subjects planned by the teacher per semester. In the preparation of DSCC, researchers consider some important aspects in the delivery of information on physical concepts. In this study, several indicators related to DSCC design for the Learning Aspect (LA) aspects are used as the following to Table 1.

Table 1. DSCC's indicators for LA

\begin{tabular}{ll}
\hline No & \multicolumn{1}{c}{ Indicators } \\
\hline 1 & Contextual problems \\
2 & Solution / Answer to the problem \\
3 & Communication effectiveness \\
\hline
\end{tabular}

For the assessment of LA indicators, a holistic method was used [14,15]. For adjustments to the needs of researchers' products, an assessment with a score of 1,2 and 3 guidelines were provided with details such as Table 2.

Table 2. Scoring guideline for LA of DSCC's indicators

\begin{tabular}{|c|c|c|c|}
\hline Indicator & 1 & 2 & 3 \\
\hline 1 & $\begin{array}{l}\text { The problem is not } \\
\text { contextual so the } \\
\text { respondent is unable to } \\
\text { identify the concept being } \\
\text { discussed }\end{array}$ & $\begin{array}{l}\text { The problem is contextual } \\
\text { but the respondent is only } \\
\text { able to identify some of } \\
\text { the concepts being } \\
\text { discussed }\end{array}$ & $\begin{array}{l}\text { The problem is contextual } \\
\text { and the respondent is able } \\
\text { to identify all concepts } \\
\text { being discussed. }\end{array}$ \\
\hline 2 & $\begin{array}{l}\text { Solutions / answers that } \\
\text { have been given are } \\
\text { unclear and incorrect and } \\
\text { very short explanations }\end{array}$ & $\begin{array}{l}\text { The solution / answer } \\
\text { given is concise, clear, and } \\
\text { precise but with less in- } \\
\text { depth explanation }\end{array}$ & $\begin{array}{l}\text { Solutions / answers given } \\
\text { are concise, clear, precise, } \\
\text { and accompanied by in- } \\
\text { depth explanation }\end{array}$ \\
\hline 3 & $\begin{array}{l}\text { Dialogue and intonation } \\
\text { are not smooth so the } \\
\text { concepts to be conveyed } \\
\text { cannot be accepted by } \\
\text { respondents }\end{array}$ & $\begin{array}{l}\text { Dialogue and intonation } \\
\text { went smoothly but the } \\
\text { concepts that they wanted } \\
\text { to display were (still) not } \\
\text { acceptable to respondents }\end{array}$ & $\begin{array}{l}\text { Dialogue and intonation } \\
\text { run smoothly so that the } \\
\text { concepts they want to } \\
\text { display can be accepted by } \\
\text { respondents very clearly }\end{array}$ \\
\hline
\end{tabular}

In the process of converting from a score to a value, all the results will be analyzed per item so that the results obtained were included in the category given by adapted $[14,15]$ as the following as like as in Table 3.

Table 3. Criteria of analysis method

\begin{tabular}{cc}
\hline $\begin{array}{c}\text { Percentage } \\
(\mathbf{\%})\end{array}$ & Criteria \\
\hline $90-100$ & Superb \\
$80-89$ & Good \\
$70-79$ & Adequate \\
$60-69$ & Bad \\
$0-59$ & Poor \\
\hline
\end{tabular}


Based on the analysis of Learning Aspect (LA) it can be stated that the highest percentage has reached was Problem Solution 93\% (superb category), then Contextual problem 80\% (good category). Based on aspects of the effectiveness of communication only reached adequate categories (73\%). Nevertheless, as many as 17\% (25 students) gave a value of 2 (good) for the communication aspect. The results of the analysis can be seen in Fig. 2. In the communication aspect, it is also known that the percentage of the number of students who gave the highest 1 (bad) score among the other categories is $10 \%$ (15 students). Students assume that the DSCC that was designed still lacked intonation, the pronunciation stopped in the wrong place (words).

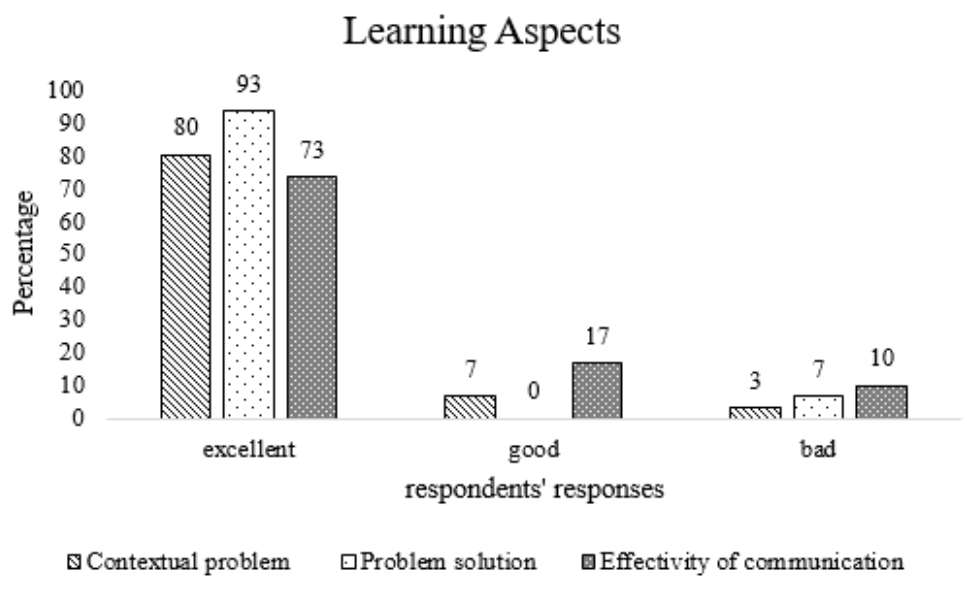

Fig 2. The result of DSCC assessment

To strengthen the results of the DSCC testing on this small scale, the researchers also gave some questions to the science teacher whose class was used for the study. All teachers were asked to provide feedback related to the implementation of DSCC with the current curriculum. The sample of teacher responses can be seen in Fig.2, while the list of indicators that teachers must respond to DSCC is provided in Table 4.

Table 4. List of indicators for DSCC

\begin{tabular}{l}
\hline \multicolumn{1}{c}{ Statements } \\
\hline Responses to DSCC that have been made \\
Skills that can be trained through DSCC \\
Advantages / challenges of implementing DSCC \\
DSCC Contribution to Learning Outcomes \\
Students' engagement in DSCC \\
\hline
\end{tabular}

In the teachers' session, researchers replaced the term DSCC with animation with the consideration that animation was more familiar than digital story conceptual change oriented. Hopefully, the assessment will be more objective because psychologically, the terms used are familiar with the respondent. As the following, several questions to investigate DSCC by teacher's view. As the following, the DSCC slideshow had shown as Fig 3. 


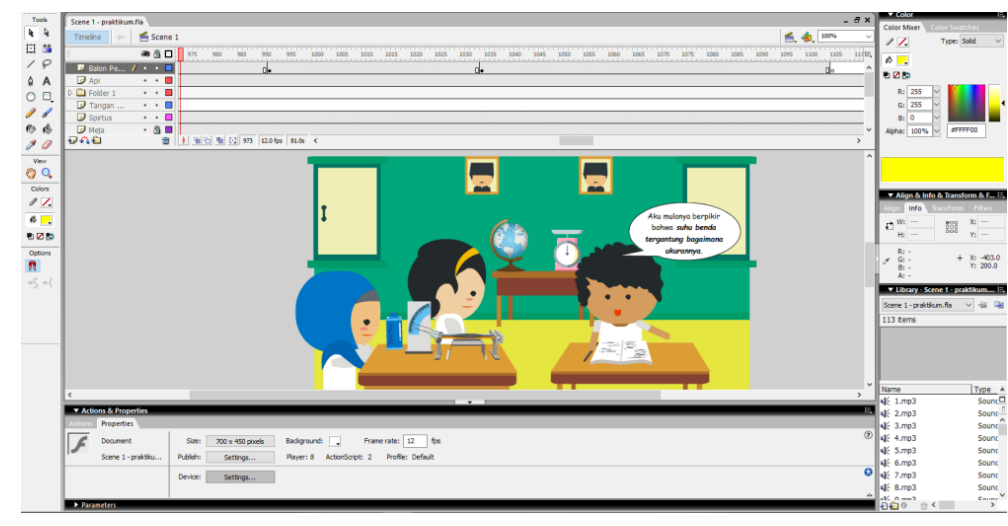

Fig 3. DSCC example in Indonesian version

In order to facilitate the researcher, as the following are the sequences of questions for the sciences teacher. The example teachers' responses had given for implementation of DSCCs were shown in Table 5.

Table 5. Response Teachers' Answers

\begin{tabular}{|c|c|c|}
\hline & Questions & Answers \\
\hline 1. & $\begin{array}{l}\text { What do you think about this } \\
\text { animation made? }\end{array}$ & $\begin{array}{l}\mathrm{T}_{2} \text { : This good animation, flow of } \\
\text { events was good, colors and audio } \\
\text { mixing process was good, clear } \\
\text { concepts, time is quite appropriate. } \\
\mathrm{T}_{4} \text { : This very good animation. }\end{array}$ \\
\hline 2. & $\begin{array}{l}\text { What are your thoughts on skills can } \\
\text { be improved from observing this } \\
\text { animations }\end{array}$ & $\begin{array}{l}\mathrm{T}_{2}: \text { The cognitive skills, because } \\
\text { this media is full of concept } \\
\text { exploration } \\
\mathrm{T}_{3}: \text { The cognitive skills }\end{array}$ \\
\hline 3. & $\begin{array}{l}\text { Do you thinks is there the advantages } \\
\text { from using this media in the } \\
\text { classroom? }\end{array}$ & $\begin{array}{l}\mathrm{T}_{1}: \text { it is easier to understand events } \\
\text { and students are more focused in } \\
\text { learning } \\
\mathrm{T}_{3}: \text { interesting animation mix makes } \\
\text { students more focused in learning }\end{array}$ \\
\hline 4. & $\begin{array}{l}\text { What are your thoughts on challenges } \\
\text { or obstacles by using this media in the } \\
\text { classroom? }\end{array}$ & $\begin{array}{l}\mathrm{T}_{2}: \text { It's so effortless to apply in our } \\
\text { class, so there are no any difficulties } \\
\text { in usage of media } \\
\mathrm{T}_{4}: \text { there are no obstacles }\end{array}$ \\
\hline 2. & $\begin{array}{l}\text { I think this media could contribute in } \\
\text { students' achievement. Would you go } \\
\text { along with that? }\end{array}$ & $\begin{array}{l}\mathrm{T}_{2}: \text { Yes, I agree with you. It should } \\
\text { be contributing for that. } \\
\mathrm{T}_{4}: \text { this media can contribute to } \\
\text { cognitive learning outcomes }\end{array}$ \\
\hline 3. & $\begin{array}{l}\text { What is your perception of students' } \\
\text { engagement in the process of } \\
\text { observing animation? }\end{array}$ & $\begin{array}{l}\mathrm{T}_{3}: \text { Students are more focused and } \\
\text { look at the screen carefully } \\
\mathrm{T}_{4}: \text { students are more focused in the } \\
\text { learning process }\end{array}$ \\
\hline
\end{tabular}

Exp: $\mathrm{T}_{1}=$ Teacher at Location 1, etc.

Based on recapitulation of teacher responses and student responses, there is continuity in every aspect of LA that is realized in the DSCC.

Based on Fig 2., DSCC's indicators had positive responses on "problem solutions and "contextual problems" that $93 \%$ and $80 \%$ respectively. This result as like as expected by researcher that "new media" could be affect to student responses. This supported that digital stories in physics could learned 
individually with anxious about places and timing to read the subject because they could look for the knowledge/ physics concepts on its displays [16]. The other factor could affect the positive responses of these are students experienced in the DSCC learning environment. Previously, students' activities only listen and write teacher's saying but now, they have option to choice the subject learning so it's being more attractive [17]. The bad responses of this media (DSCC) gave by $3 \%$ student for contextual problems indicator, $7 \%$ of all students for problem solutions and the highest $10 \%$ of all student for effectivity communication. The analysis of bad responses for two of them (contextual problem and problem solutions indicators) that student overall less concentrate to observe the information that deliver by DSCC display. The consequences of this problem was student unable to give an accurate feedback for their teacher about their observation digital stories [18].

A slightly different finding was seen in the communication aspect. The teacher considers that there is no communication problem at DSCC because all students focus on the DSCC program $\left(T_{1}, T_{2}, T_{3}\right.$ and $\mathrm{T}_{4}$ ). However, the response given by students (refers to Table 1) is that there is a slight problem in the communication aspect (10\% of students).

This result shown that "communication" had the lowest response because based on the prototype DSCC that has been converted from .avi, .fla, .swf, .jpg /.png, .mp3 to mp4 for simplification of usage of DSCC. The displays were found that the sentences pronunciation was halting, and there are some parts of the conversation that use incorrect intonation. In addition, when showing DSCC at some schools in West Singkawang, there were still some students who did not focus/ concentrate to DSCC. In previous research, it has been proven that the usage of (electronic-based) media in learning is not always successful because there are some students who do not comply with teachers' guidance or technology devices that are not compatible to play media so that the display was slightly disrupted [19]. The results of this negative feedback are clearly written that the vocalization of unattractive figures influences the achievement of the learning objectives had been made by the teacher [10]. In other words, the process of making a digital story needs a variety of problem solving including story scenes, background music, intonation and character voices in explaining concepts [6]. In the DSCC screening process that does not run smoothly, it can causation of students to only be able to record/ write some data from the scientific problems that are presented so they gave also unrelated solutions [20]. In summary, if the information processing from DSCC was problematic then students will also give wrong respond.

From all aspects of LA shown, there are three indicators of LA that are given the lowest score, namely 1: Contextual Problem gets 3\% (five students), Problem Solution gets 7\% of students (10 students) and Effectiveness of Communication $10 \%$ of students (15 students). If all of these are added together, there will be a total of 35 people ( $24 \%$ of 147 respondent) give the "bad responses" of this product (DSCC) in the limited scale of this development project. There are some limitations from this study. First, (refer to communication indicator) there were finding that students had difficulty to capture representative information in DSCS's displays. If the display shown is a single concept, then it is not sufficient to meet all aspects needed so that it can pass through an important part, especially from cross-disciplines [21]. The second, this is a prototype product so it has to repair for the advance testing in large scale. But overall, all students' responses are positive. Thus, it can be said that digital story is a powerful instrument for creating an interesting, fun learning environment and is able to connect problems contextually [22]. The reflection of this result was focused on the students' difficulties to capture the information in the digital stories learning [23]. If the revision of products had been proposed it could have warranted that students' excitement to engage directly in creating digital story were arising. It implies that their motivation and confidences were boosted [24]. In the process of implementing of DSCC to students it recommended to include this media into learning model its belong to standardize all of terms that used in DSCC with knowledge background of the researchers [25]. That means the creating of DSCC could be improve accord with researchers' goals.

With these findings, researchers will improve DSCC specifically in the aspect of communication. The ultimate goal of developing DSCC is practicality in use without having to make drastic changes to teaching methods. In case improving indicators of "problem solution", researchers will improve the 
conceptions that are displayed so that they are more profound and easily digested by students. With this limited scale test, it is expected that the final product will be better and can be applied easily.

\section{CONCLUSION AND SUGGESTION}

Based on the analysis of the results and discussion, it can be concluded that the development of this product could be advance to next stage (that is to large test scale) which the Learning Aspect testing had shown that $93 \%$ (137 students) agree that problem solution had suitable with its problem and the worst responses was $10 \%$ (15 students) for "communication aspect. This result determined by using rubric sheet by holistic method. The limitation of this study was testing in limited scale so this data could be suggestions for the researcher to enhance the product quality (DSCC's quality) so it able to facilitate the conceptual change process. In order to optimize the DSCC design, especially to produce the better learning outcomes, teachers must often practices using DSCC both technically and conceptually.

\section{ACKNOWLEDGMENTS}

The researchers would like to acknowledge DRPM Kemenristekdikti for the implementation of this research through the Research Grant Program: Penelitian Dosen Pemula with contract: 619 / L11 / KM/ 2019.

\section{REFERENCES}

[1] Suyono, S. (2014). Misconception Prevention of Senior High School Students on Chemistry Concepts Using Several Inquiry-Based. In Proceeding of International Conference on Research, Implementation and Education, pp. 105-112.

[2] Azman, N. F., Alia, M., \& Mohtara, L. E. (2013). The Level of Misconceptions on Force and Motion Among Physics Pre-service Teachers in UPSI (Doctoral dissertation, Universiti Teknologi Malaysia).

[3] Halim, L., Yong, T. K., \& Meerah, T. S. M. (2014). Overcoming students' misconceptions on forces in equilibrium: An action research study. Creative Education, 5(11): 1032.

[4] Hasmiati, H., Jamilah, J., \& Mustami, M. K. (2017). Aktivitas dan Hasil Belajar Siswa Pada Pembelajaran Pertumbuhan dan Perkembangan Dengan Metode Praktikum. Jurnal Biotek, 5(1): 21-35.

[5] Ginting, S. M., \& Hermansyah, A. (2012). Penerapan Model Pembelajaran Somatis Auditori Visual dan Intelektual (SAVI) Berbantuan Media Komputer untuk Meningkatkan Kualitas Pembelajaran Kimia Fisika II. Exacta, 10(1): 98-105.

[6] Vivitsou, M., Niemi, H., Wei, G., Kallunki, V., \& Miao, R. (2017, October). Teachers' practices to support student work in digital storytelling: A study on Finnish and Chinese school teachers' experiences. In Seminar. net (Vol. 13, No. 2).

[7] Batsila, M., \& Tsihouridis, C. (2016). " Once upon a Time there was..." A Digital World for Junior High School Learners. International Journal of Emerging Technologies in Learning (iJET), 11(03): 42-50.

[8] Prins, E. (2017). Digital storytelling in adult education and family literacy: A case study from rural Ireland. Learning, Media and Technology, 42(3): 308-323.

[9] Maddine, E. (2014). Monitoring and Assessing Digital Story Projects in Middle Grades English Language Arts. Kentucky Journal of Excellence in College Teaching and Learning, 12(2014): 1.

[10] Karaoglan Yilmaz, F. G., Özdemir, B. G., \& Yasar, Z. (2018). Using digital stories to reduce misconceptions and mistakes about fractions: an action study. International Journal of Mathematical Education in Science and Technology, 49(6): 867-898. 
[11] Psomos, P., \& Kordaki, M. (2015). A novel educational digital storytelling tool focusing on students misconceptions. Procedia-Social and Behavioral Sciences, 191: 82-86.

[12] Alcantud Diaz, M. (2016). Digital Storytelling with Pre-Service Teachers. Raising Awareness for Refugees through ICTS in ESL Primary Classes. Digital Education Review, 30: 1-16.

[13] Wang, S., \& Zhan, H. (2010). Enhancing teaching and learning with digital storytelling. International Journal of Information and Communication Technology Education (IJICTE), 6(2): 76-87.

[14] Zlatkin-Troitschanskaia, O., Shavelson, R. J., Schmidt, S., \& Beck, K. (2019). On the complementarity of holistic and analytic approaches to performance assessment scoring. British Journal of Educational Psychology.

[15] Metruk, R. (2018). Comparing Holistic and Analytic Ways of Scoring in the Assessment of Speaking Skills. Journal of Teaching English for Specific and Academic Purposes, 6(1): 179189.

[16] Kotluk, N., \& Kocakaya, S. (2016). Researching and evaluating digital storytelling as a distance education tool in physics instruction: An application with pre-service physics teachers. Turkish Online Journal of Distance Education, 17(1): 87-99.

[17] Wartono, D. H., \& Nilasari, \& Batlolona, J. R. (2019). Real-virtual monte carlo simulation on impulse-momentum and collisions. Indonesian Journal of Electrical Engineering and Computer Science, 13(1): 7-14.

[18] Lestariyana, R. P. D., \& Widodo, H. P. (2018). Engaging young learners of English with digital stories: Learning to mean. Indonesian Journal of Applied Linguistics, 8(2): 489-495.

[19] Mabruri, H., Ahmadi, F., \& Suminar, T. (2019). The Development of Science Mobile Learning Media to Improve Primary Students Learning Achievements. Journal of Primary Education, 8(1): 108-116.

[20] Cheng, M. M., \& Chuang, H. H. (2019). Learning Processes for Digital Storytelling Scientific Imagination. EURASIA Journal of Mathematics, Science and Technology Education, 15, 2.

[21] Choi, G. Y. (2018). Learning through digital storytelling: exploring entertainment techniques in lecture video. Educational Media International, 55(1): 49-63.

[22] Özpinar, İ., Gökçe, S., \& Yenmez, A. A. (2017). Effects of Digital Storytelling in Mathematics Instruction on Academic Achievement and Examination of Teacher-Student Opinions on the Process. Journal of Education and Training Studies, 5(10): 137-149.

[23] Yildiz Durak, H. (2018). Digital story design activities used for teaching programming effect on learning of programming concepts, programming self-efficacy, and participation and analysis of student experiences. Journal of Computer Assisted Learning, 34(6): 740-752.

[24] Nassim, S. (2018). Digital Storytelling: An Active Learning Tool For Improving Students'language Skills. PUPIL: International Journal of Teaching, Education and Learning, 2(1).

[25] Hussain, H., \& Shiratuddin, N. (2016, August). The digital storytelling process: A comparative analysis from various experts. In AIP Conference Proceedings (Vol. 1761, No. 1, p. 020044). AIP Publishing. 